\title{
Distribuição do Toxoplasma gondii Nicolle \& Manceaux, 1909 (Apicomplexa: Toxoplasmatinae) em órgãos de camundongos albinos inoculados com uma amostra acistogênica: dados preliminares
}

\author{
Distribution of acystogenic Toxoplasma gondii Nicolle \& Manceaux, 1909 \\ (Apicomplexa: Toxoplasmatinae) in organs of albino mice: preliminary data
}

\author{
George Rego Albuquerque ${ }^{1}$, Alexandre Dias Munhoz', Simoni Machado de Medeiros², Walter Flausino ${ }^{3}$, \\ Carlos Wilson Gomes Lopes ${ }^{4}$
}

\section{Resumo}

Vinte camundongos albinos fêmeas foram inoculados por via sub-cutânea com $10^{3}$ taquizoítas de Toxoplasma gondii. Quarenta outros animais foram usados como controles, sendo 20 como controle alimentar e 20 como controle negativo. Taquizoítas foram observados em um dos animais inoculados no $5^{\circ}$ dia após infecção (DAl), caracterizando-se como formas finas e pequenas. Do $11^{\circ}$ ao $13^{\circ}$ DAl, taquizoítas finos e largos foram observados em esfregaços do fígado, baço, pulmões, rins e coração. Os animais controles foram negativos para $T$. gondii.

Palavras-chave: Toxoplasma gondii; taquizoítas; camundongos

O Toxoplasma gondii (Nicolle \& Manceaux, 1909) é um parasita heteroxeno facultativo. Seu ciclo de vida completo só pode ser realizado no hospedeiro definitivo, os felídeos. Contudo, várias espécies de animais entre mamíferos e aves têm sido considerados como hospedeiros intermediários (Levine, 1977).

A demonstração do parasito em tecidos, por exames histopatológicos, é muito difícil. Existem, atualmente, duas técnicas que podem ser usadas para demonstração de antígenos ou protozoário nas lesões teciduais: a imunofluorescência e a peroxidase anti-peroxidase (Kanamura-Kawada et al., 1986). Por outro lado pode ser feita a tentativa de isolamento do coccídio em camundongo por inoculações subcutâneas de órgãos, a partir de tecidos (Peixoto, 1990).

Após a necropsia dos 20 camundongos albinos, fêmeas, inoculados com $10^{3}$ de taquizoítas por via subcu- tânea, com uma amostra isolada de coração de galinha naturalmente infectada, observou-se que em três deles não houve infecção no 1ํ, $3^{\circ}$ e $7^{\circ}$ dia após infecção (DAI), embora formas finas e pequenas de $T$. gondiitenham sido encontradas em um dos camundongos no $5^{\circ}$ DAI. Nos $11^{\circ}, 12^{\circ}$ e $13^{\circ}$ DAl foram necropsiados dois, um e três camundongos respectivamente. Sinais como apatia, pêlos eriçados e taquipnéia foram observados nos animais infectados. Formas finas e largas de T. gondii foram encontradas no fígado, no baço, nos pulmões, nos rins e no coração (Tabela). Verificou-se também que houve redução apesar de o o peso vivo desses animais não ter se alterado em relação à pesagem das carcaças e que as vísceras desses animais foram mais pesadas quando comparadas com as dos grupos controles. Não se observaram formas do parasita em esfregaços do cérebro dos animais infectados. Em relação aos grupos controles negativo e alimentar nenhum dos esfregaços examinados foi positivo.

Tabela - Percentagem de taquizoítas de Toxoplasma gondii observados em órgãos de camundongos inoculados subcutaneamente com $10^{3}$ taquizoítas

\begin{tabular}{lcc}
\hline \multirow{2}{*}{ Órgãos } & \multicolumn{2}{c}{ Formas (\%) $^{\star}$} \\
\cline { 2 - 3 } & Finas & Largas \\
\hline Fígado & 26 & 74 \\
Baço & 38 & 62 \\
Pulmões & 47 & 53 \\
Rins & 52 & 48 \\
Coração & 50 & 50 \\
\hline
\end{tabular}

* Mensurados 100 taquizoítas por órgão examinado

\footnotetext{
1 Bolsista de Iniciação Científica - PIBIC/CNPq/UFRRJ

${ }^{2}$ Curso de Pós-Graduação em Medicina Veterinária, Parasitologia Veterinária, UFRRJ

${ }^{3}$ Curso de Pós-Graduação em Microbiologia Veterinária, UFRRJ

${ }^{4}$ Departamento de Parasitologia Animal//B, Universidade Federal Rural do Rio de Janeiro, 23851-970 Seropédica, RJ, Brasil
} 


\section{Abstract}

Distribution of acystogenic Toxoplasma gondii Nicolle \& Manceaux, 1909 (Apicomplexa: Toxoplasmatinae) in organs of albino mice: preliminary data

Twenty female albino mice were inoculated subcutaneously wich $10^{3}$. Toxoplasma gondii tachizoites. Fourty mice were used as controls, 20 were used as per fed and 20 were negative ones. Tachizoites were observed in one of the inoculated animals at the 5 th day after infection (DAI) and they were characterized as slender and small forms. At 11th to 13th DAl, slender and wide tachizoites were observed in tissues smears of liver, spleen, lungs, kidneys, and heart. The control animals remained negative for $T$. gondii.
Key words: Toxoplasma gondir, tachizoites; albino mice

\section{Referências bibliográficas}

KANAMURA-KAWADA, H.Y., MADEIRA, L.H.A., CAMARGO, M.E., ALVES, V.A.F., LOPES, M.B.S., ROSEMBERG, S. Identificação do Toxoplasma gondii pela técnica imunohistoquímca da peroxidase anti-peroxidase. Estudo comparativo. Rev. Soc. Bras. Med. Trop., v. 19, p. 114, 1986.

LEVINE, N.D. Taxonomy of Toxoplasma. J. Protozool., v. 24, p. 36-41, 1977.

PEIXOTO, C.M.S. Isolamento do Toxoplasma gondii Nicolle \& Manceaux, 1909 (Apicomplexa: Toxoplasmatinae) de galinhas naturalmente infectadas. Rio de Janeiro, 1990. 99 p. Tese de Mestrado em Medicina Veterinária-Parasitologia Veterinária. Universidade Federal Rural do Rio de Janeiro. 